Brit. J. vener. Dis. (1958), 34, 70.

\title{
A COMPARISON OF THE IN VITRO SENSITIVITY OF GONOCOCCI TO PENICILLIN WITH THE RESULTS OF TREATMENT*
}

\author{
BY \\ F. R. CURTIS AND A. E. WILKINSON \\ Whitechapel Clinic, The London Hospital, and the V.D. Reference Laboratory, Medical Research Council, London
}

The great success which followed the adoption of penicillin as the drug of choice for the treatment of gonorrhoea, coming as it did at a time when the organism was becoming increasingly resistant to the sulphonamides, led to hopes that the control of gonorrhoea might be in sight. Although in Great Britain and other countries there was a marked decline in the number of reported cases in the immediate post-war years, the rate of decline then lessened and since 1955 there has been a steady increase in the number of patients attending V.D. Clinics with gonorrhoea (C.M.O.'s Report, 1957; King, 1958).

At the end of 1956 it was noticed that a small proportion of male patients attending the Whitechapel Clinic with uncomplicated gonococcal urethritis was failing to respond to the routine treatment of 300,000 units procaine penicillin given intramuscularly and continued to show gonococci in their discharges. In many of these cases, further treatment with larger doses of penicillin was equally unsuccessful. As re-infection seemed an unlikely explanation, an investigation of the in vitro sensitivity of the infecting strains was undertaken (A.E.W.):

(1) To compare the range of sensitivity of currently isolated strains of gonococci to penicillin with those reported in earlier surveys.

(2) To try to correlate the penicillin sensitivity of the infecting strain with the response to treatment with penicillin.

\section{Part I. Bacteriological Aspects}

Technical Methods.--Specimens of urethral discharge were collected on charcoal-impregnated swabs, placed in Stuart's transport medium (Moffatt, Young, and Stuart, 1948), and kept in the refrigerator until they could be plated out on chocolate agar. After inoculation, plates were incubated at $36^{\circ} \mathrm{C}$. in candle jars for $48 \mathrm{hrs}$. Gramstained films were made from representative colonies and subcultures made to chocolate agar plates for

\footnotetext{
* Paper read to M.S.S.V.D., April 25, 1958. Received for publica-
} tion April 15, 1958. plate sensitivity tests and to carbon serum agar slopes for tube sensitivity tests. The oxydase reaction was checked by applying a loopful of 0.5 per cent. aqueous p-phenylenediamine hydrochloride to the remains of the colonies on the primary plate after the subcultures had been carried out.

Plate Sensitivity Test.-This was performed by the technique described by Stokes (1955). Two strains of gonococci were streaked over halves of a chocolate agar plate so that a gap of about $1 \mathrm{~cm}$. separated them in the middle of the plate. $4 \mathrm{ml}$. broth was inoculated with a 3-mm. loopful of an overnight broth culture of the Oxford staphylococcus and a loopful of the diluted suspension spread down the central gap separating the two cultures of gonococci. A sterile $9-\mathrm{mm}$. disk of filter paper, on which 10 units of penicillin had been dried, was placed in the centre of the plate which was incubated overnight in a candle jar. After flooding with oxydase reagent, the plate was allowed to dry off and the zones of inhibition of growth from the margin of the disk were measured with dividers and compared with the mean of the readings for the staphylococcus. The sensitivity of the gonococci was expressed qualitatively as equal to, greater or less than that of the standard staphylococcus.

Tube Sensitivity Test.-The medium used had the following composition;

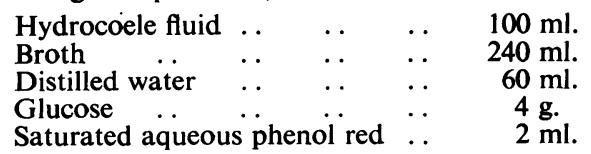

The $\mathrm{pH}$ was adjusted to $7 \cdot 4-7 \cdot 5$ and the medium sterilized by Seitz filtration and distributed in $25 \mathrm{ml}$. amounts in screw-capped bottles which were incubated overnight to check sterility and then stored in the refrigerator until needed. The medium kept well for at least a month under these conditions.

A stock solution of 500 units penicillin per $\mathrm{ml}$. was prepared by dissolving a 10,000 unit tablet of crystalline penicillin $G$ in $20 \mathrm{ml}$. sterile saline. This standard solution was stored at $-20^{\circ} \mathrm{C}$. and freshly prepared every 2 to 3 weeks. From it a series of 
doubling dilutions in the glucose hydrocoele broth were made to give a range of penicillin concentrations from 0.5 to 0.004 units $/ \mathrm{ml}$. At each batch of tests a sufficient volume of the range was prepared to cover the number of strains to be tested, and $0.5 \mathrm{ml}$. amounts of these master dilutions were transferred to sterile $7 \times 1 \mathrm{~cm}$. tubes closed with loosely fitting aluminium caps, together with one tube of $0.5 \mathrm{ml}$. medium without added penicillin to act as a control for each strain tested.

The inoculum of the gonococcus under examination was prepared by emulsifying the growth of an overnight culture on a carbon serum agar slope as evenly as possible in about $1 \mathrm{ml}$. broth and transferring sufficient of this suspension to a further $1 \mathrm{ml}$. of broth so as to give a barely detectable turbidity. $0.02 \mathrm{ml}$. amounts of this diluted suspension were added to each tube of the set of penicillin dilutions, to the control, and to a hydrocoele agar slope containing 1 per cent. maltose and phenol red by means of a standard dropping pipette. Most strains of gonococci gave even suspensions in broth if young overnight cultures were used, but a minority gave granular suspensions which could not be evenly suspended. Experiments, in which the size of the inoculum was varied widely, showed that this was without effect on the final result so that no attempt at more precise standardization of the inoculum was made. Each batch of tests included a set of penicillin dilutions inoculated with $0.02 \mathrm{ml}$. of the diluted broth suspension of the Oxford staphylococcus prepared as described for the plate sensitivity test.

Tests were examined after overnight incubation at $36^{\circ} \mathrm{C}$. and a final reading was made at $48 \mathrm{hrs}$ (or at $72 \mathrm{hrs}$ where a weekend intervened). The endpoint of minimal inhibitory concentration was taken as the greatest dilution of penicillin which showed no visible growth. Gram-stained films were made from the last tube showing visible growth to avoid errors due to accidental contamination of cultures. The production of acid by fermentation of glucose in the medium together with growth without acid production on the maltose hydrocele agar slope completed the identification of the organism as a gonococcus.

Tests for sensitivity to streptomycin were carried out in the same medium, dilutions from a stock solution of $5,000 \mu \mathrm{g}$. streptomycin sulphate in saline being made to give a series of six doubling dilutions from 10 to $0 \cdot 3 \mu \mathrm{g} . / \mathrm{ml}$.

Strains of Gonococci Examined.-During the period April-December, 1957, a total of 468 cultures was examined, this total including repeated tests on some patients. The great majority of the cultures ( 93 per cent.) were from male patients; this was a deliberate choice because of the relative ease of obtaining pure cultures from the primary growths in such cases. In 391 cases $(83.5$ per cent.) gonococci were isolated and fully identified and sensitivity tests were carried out. In a further 24 cases $(5 \cdot 1$ per cent.) organisms having the morphological appearance of gonococci were isolated but were lost in subculture before tests for sensitivity or full identification could be performed. These are referred to in the text as "Presumptive Gonococci". In the remaining $53(11 \cdot 3$ per cent.) no gonococci were grown.

During the period under review, an attempt was made to determine the sensitivity to penicillin of gonococci from those patients who failed to respond to pencillin therapy and from as many routine pretreatment cultures as possible. Owing to staff shortages the survey was considerably reduced during the summer and the bulk of the examinations were made during April and May and from October to December.

\section{Results}

Comparison of Plate and Tube Sensitivity Tests.The results of 185 parallel tests by the two methods are shown in Table I. Where more than one strain had been isolated from an individual in the course of his infection, only the first strain examined has been included.

TABLE I

COMPARISON OF PARALLEL PLATE AND TUBE SENSITIVITY TESTS ON 185 STRAINS OF GONOCOCCI

\begin{tabular}{c} 
Plate Sensitivity \\
\cline { 2 - 3 }
\end{tabular}


Table I shows that, where the strain of gonococcus was definitely less or more sensitive than the reference staphylococcus on the plate test, there was fairly good correlation with the results of the more accurate tube test. Where the sensitivity of the two organisms was apparently equal on the plate test, there was a much greater range of sensitivities in the tube test, and because of the uncertainty of interpretation of results in this group of strains the use of the plate test as a routine was abandoned.

Sensitivity of the Gonococcus by the Tube Test.The results of tests on strains of gonococci isolated from 340 patients are shown in Table II. In many cases more than one isolation was made during the course of the infection; to obviate duplication of results only the sensitivities of the strains first isolated are recorded.

TABLE II

DISTRIBUTION OF SENSITIVITIES OF STRAINS OF GONOCOCCI ISOLATED FROM 340 PATIENTS

\begin{tabular}{l|c|c|c|c|c|c|c|c}
\hline $\begin{array}{c}\text { Minimal } \\
\text { Inhibitory } \\
\text { Concentra- } \\
\text { tion of } \\
\text { Penicillin } \\
\text { (units/ml.) }\end{array}$ & 0.5 & 0.25 & 0.125 & 0.06 & 0.03 & 0.015 & 0.008 & $\geqslant 0.004$ \\
\hline $\begin{array}{l}\text { Number of } \\
\text { Strains .. }\end{array}$ & 13 & 51 & 19 & 18 & 22 & 77 & 101 & 39 \\
\hline $\begin{array}{l}\text { Per cent. of } \\
\text { Total .. }\end{array}$ & 3.8 & 15.0 & $5 \cdot 6$ & 5.3 & 6.5 & 22.6 & 29.7 & $11 \cdot 5$ \\
\hline
\end{tabular}

As mentioned above, attempts were particularly made to isolate strains from treatment failures. As such cases gave one or more opportunities to retrieve a strain which might not have been grown at the primary culture, while this chance was not offered by those cases where treatment was successful, these figures are biased and show an undue preponderance of strains from patients where treatment had failed. To obviate this, cases have been selected from the group of 340 patients where the strain of gonococcus was isolated at the patient's first attendance at the clinic, before treatment was given. 302 cultures which fulfilled this criterion were available and the results of sensitivity tests on these are shown in Table III. A comparison of Tables II and III shows that the group of strains isolated at first attendances shows a slightly lower incidence of the most resistant strains, and it is felt that this group gives a more reliable index of the distribution of sensitivity to penicillin among gonococci during the period under review and is the nearest approach possible to an unselected sample with the material available.

In order to see if there had been any change in the distribution of sensitivities of gonococci isolated early
TABLE III

DISTRIBUTION OF SENSITIVITIES OF STRAINS OF GONOCOCCI ISOLATED FROM 302 PATIENTS AT THEIR FIRST ATTENDANCE BEFORE TREATMENT WAS GIVEN

\begin{tabular}{l|c|c|c|c|c|c|c|c}
\hline $\begin{array}{c}\text { Minimal } \\
\text { Inhibitory } \\
\text { Concentra- } \\
\text { tion of } \\
\text { Penicillin } \\
\text { (units/ml.) }\end{array}$ & 0.5 & 0.25 & 0.125 & 0.06 & 0.03 & 0.015 & 0.008 & $\geqslant 0.004$ \\
\hline $\begin{array}{l}\text { Number of } \\
\text { Strains .. }\end{array}$ & 5 & 38 & 16 & 17 & 20 & 73 & 94 & 39 \\
\hline $\begin{array}{l}\text { Per cent. of } \\
\text { Total }\end{array}$ & 1.6 & 12.6 & 5.3 & 5.6 & 6.6 & $24 \cdot 2$ & $31 \cdot 2$ & 12.9 \\
\hline
\end{tabular}

and late in the investigation, the results obtained in April and May are compared with those of November and December in Table IV. Only strains isolated at the patient's first attendance are included.

TABLE IV

COMPARISON OF SENSITIVITIES OF GONOCOCCI ISOLATED AT THE BEGINNING AND END OF THE SURVEY

\begin{tabular}{|c|c|c|c|c|}
\hline \multirow{2}{*}{$\begin{array}{l}\text { Minimal } \\
\text { Inhibitory } \\
\text { Concentration } \\
\text { of Penicillin } \\
\text { (units } / \mathrm{ml} \text {.) }\end{array}$} & \multicolumn{2}{|c|}{ April and May } & \multicolumn{2}{|c|}{$\begin{array}{l}\text { November and } \\
\text { December }\end{array}$} \\
\hline & $\begin{array}{l}\text { No. of } \\
\text { Strains }\end{array}$ & $\begin{array}{l}\text { Percentage } \\
\text { Positive* }\end{array}$ & $\begin{array}{l}\text { No. of } \\
\text { Strains }\end{array}$ & $\begin{array}{l}\text { Percentage } \\
\text { Positive* }\end{array}$ \\
\hline $\begin{array}{l}0.5 \\
0.25 \\
0.125 \\
0.06 \\
0.03 \\
0.015 \\
0.008 \\
\geqslant 0.004\end{array}$ & $\begin{array}{r}1 \\
7 \\
9 \\
5 \\
6 \\
40 \\
28 \\
5\end{array}$ & $\begin{array}{r}1 \cdot 0 \\
6 \cdot 9 \\
8 \cdot 9 \\
5 \cdot 0 \\
5 \cdot 9 \\
39 \cdot 6 \\
27 \cdot 7 \\
5 \cdot 0\end{array}$ & $\begin{array}{r}4 \\
22 \\
5 \\
8 \\
8 \\
15 \\
48 \\
23\end{array}$ & $\begin{array}{r}3 \cdot 0 \\
16 \cdot 5 \\
3 \cdot 8 \\
6 \cdot 0 \\
6 \cdot 0 \\
11 \cdot 3 \\
36 \cdot 1 \\
17 \cdot 3\end{array}$ \\
\hline Total & \multicolumn{2}{|l|}{101} & \multicolumn{2}{|l|}{133} \\
\hline
\end{tabular}

* These percentages refer to the total number of strains examined in each period.

These results show some difference in the pattern of the distribution of sensitivities of gonococci isolated during the two periods. During the last 2 months of the year proportionately twice as many of the most resistant strains (sensitive only to 0.5 or 0.25 units $/ \mathrm{ml}$.) were found as compared with the earlier period. At the same time there was an increase in the proportion of the most sensitive strains $(\leqslant 0.004$ units $/ \mathrm{ml}$.) isolated during November and December.

More than one culture had been taken from 54 patients, many of whom were treatment failures. The results of sensitivity tests on these strains were examined to see whether any change in sensitivity could be detected during the course of treatment. Unfortunately the result of only one test was available in sixteen of these cases, gonococci not having been grown on the second occasion in twelve, and the strains having been lost in subculture in four. In one case no gonococci were grown at either test, 
and in a further patient only a plate test had been carried out when he first attended; the gonococcus isolated was less sensitive than the reference staphylococcus and a subsequent tube test on a second specimen showed that the strain was sensitive to 0.25 units $/ \mathrm{ml}$. In 36 patients, however, the results of two or more tube tests were available for comparison, two tests having been carried out in 24 cases, three in ten cases, and four or more in two cases. In 23 instances, tests on two or more strains isolated from the same patient showed identical sensitivities; in eight cases there was a variation of one dilution, the sensitivity having risen in four and fallen in four; changes of this degree are not thought to be necessarily significant. The results of some of these multiple tests are shown in Table V.

TABLE V

RESULTS OF SENSITIVITY TESTS WHERE MORE THAN ONE STRAIN WAS ISOLATED FROM A PATIENT

\begin{tabular}{|c|c|c|c|c|c|}
\hline \multirow{2}{*}{$\begin{array}{l}\text { Case } \\
\text { No. }\end{array}$} & \multicolumn{3}{|c|}{$\begin{array}{c}\text { Sensitivity } \\
\text { (units/ml.) Strains }\end{array}$} & \multirow{2}{*}{$\begin{array}{c}\text { Interval } \\
\text { between } \\
\text { Discrepant } \\
\text { Tests } \\
\text { (days) }\end{array}$} & \multirow[t]{2}{*}{ Remarks } \\
\hline & 1 & 2 & 3 & & \\
\hline $\begin{array}{l}15006 \\
18904 \\
20080 \\
20094 \\
14034\end{array}$ & $\begin{array}{l}0.03 \\
0.06 \\
0.008 \\
0.008 \\
0.25\end{array}$ & \begin{tabular}{r|}
0.008 \\
0.008 \\
$\geqslant 0.004$ \\
$\geqslant 0.004$ \\
0.25
\end{tabular} & $\begin{array}{c}\bar{z} \\
\bar{z} \\
0 . \overline{008}\end{array}$ & $\begin{array}{l}16 \\
15 \\
10 \\
18 \\
23\end{array}$ & Fresh infections \\
\hline 20124 & 0.03 & 0.03 & 0.03 & & $\begin{array}{c}\text { Relapses } \\
\text { parently } \\
\text { strain }\end{array}$ sensitive \\
\hline 18844 & $\overline{0.008}$ & 0.008 & $\overline{0.008}$ & & $\begin{array}{l}\text { Probable re-infections } \\
\text { from same contact }\end{array}$ \\
\hline $\begin{array}{l}20126 \\
32415\end{array}$ & $\begin{array}{l}0.25 \\
0.25\end{array}$ & $\begin{array}{l}0 \cdot 25 \\
0 \cdot 25\end{array}$ & $\stackrel{*}{0}$ & & $\begin{array}{l}\text { Strains from two con- } \\
\text { tact cases }\end{array}$ \\
\hline
\end{tabular}

* Presumptive gonococci, strain lost in subculture.

No evidence was found from these examinations to suggest that treatment of a patient harbouring a penicillin-insensitive strain of gonococcus with penicillin resulted in any enhancement of the re- sistance of the strain. It should be noted, however, that a series of doubling dilutions as used in the tube test, so that only relatively large changes in resistance would be detected by this technique. In all cases where a difference of two dilution steps or more was found between the two determinations a fresh infection was probable on clinical grounds. Two patients (20126 and 32415) were known to be infected with the same strain, a husband having infected his wife and having in his turn been reinfected by her. All five strains isolated from this pair were found, as was to be expected, to have the same sensitivity to penicillin. One patient (18844) was thought to have acquired three infections from the same woman; all three strains isolated from him had the same sensitivity.

One patient was investigated in some detail. After he had failed to respond to the routine dose of 300,000 units of procaine penicillin, it was decided to give a series of injections of crystalline penicillin $G$ with the object of securing a high blood level for at least 12 hours. The bacteriological findings are summarized in Table VI.

After treatment with the crystalline penicillin $G$ had been started, there was a marked lessening in the amount of urethral discharge and the patient no longer complained of dysuria. This clinical improvement was accompanied by a marked and progressive drop in the number of gonococci seen in stained smears of discharge when these were examined by a rough quantitative method. The cytological appearances of the discharge also changed, the proportion of pus cells decreasing and epithelial cells re-appearing, giving the appearance of an acute inflammatory process which was beginning to regress. However, as soon as penicillin treatment was stopped, gonococci re-appeared in the urethral discharge in increasing numbers. Streptomycin was then given and this resulted in a prompt clinical and

TABLE VI

SUMMARY OF BACTERIOLOGICAL FINDINGS IN A CASE OF PENICILLIN-RESISTANT GONORRHOEA

\begin{tabular}{|c|c|c|c|c|c|c|c|c|}
\hline \multirow{2}{*}{\multicolumn{2}{|c|}{ Date and Time }} & \multicolumn{4}{|c|}{ Urethral Smear } & \multirow{3}{*}{$\begin{array}{l}\begin{array}{c}\text { No. of } 1 / 12^{n} \text { Fields } \\
\text { containing Gc in } \\
\text { Fifty Consecutive } \\
\text { Fields Searched }\end{array} \\
\text { Not Examined }\end{array}$} & \multirow{3}{*}{$\begin{array}{c}\begin{array}{c}\text { Culture } \\
\text { Sensitivity } \\
\text { (units/ml.) }\end{array} \\
0 \cdot 25\end{array}$} & \multirow{3}{*}{$\begin{array}{c}\text { Treatment } \\
\text { Procaine Penicillin (300,000 units) }\end{array}$} \\
\hline & & \multirow{2}{*}{$\frac{\text { Gc }}{++}$} & \multirow{2}{*}{$\frac{\text { Pc }}{+++}$} & \multirow{2}{*}{ Ec } & \multirow{2}{*}{ so } & & & \\
\hline Oct. 16 & $\ldots$ & & & & & & & \\
\hline Oct. 18 & $\begin{array}{l}11 \text { a.m. } \\
1.30 \text { p.m. } \\
4 \text { p.m. } \\
6.30 \text { p.m. }\end{array}$ & $\begin{array}{l}++ \\
\pm \\
\text { Oc. } \\
\text { Oc. }\end{array}$ & $\begin{array}{l}+++ \\
++ \\
++ \\
++\end{array}$ & $\begin{array}{l}\text { Oc. } \\
\text { Oc. } \\
\pm \\
\pm\end{array}$ & $\overline{\overline{O c}}$ & $\begin{array}{c}50 \\
14 \\
2 \\
\text { (single diplococci only) } \\
0\end{array}$ & $\begin{array}{l}0 \cdot 5 \\
0 \cdot 5 \\
0 \cdot 5 \\
\text { No Gc. } \\
\text { Grown }\end{array}$ & $\begin{array}{c}\text { Crystalline Penicillin } G \\
(300,000 \text { units at } 11 \text { a.m., } 1.30 \text { p.m., } \\
\text { and } 4 \text { p.m.) }\end{array}$ \\
\hline Oct. 19 & 2. 30 p.m. & \pm & ++ & + & - & 10 & $0 \cdot 5$ & \\
\hline Oct. 21 & .. & ++ & +++ & Oc. & - & 50 & $\begin{array}{l}\text { No Gc. } \\
\text { Grown } \\
\text { (Proteus) }\end{array}$ & Streptomycin (1 g.) \\
\hline
\end{tabular}


bacteriological cure. It seems probable in this case that the treatment with crystalline penicillin $G$ resulted in the destruction of the majority of the gonococci although the strain was a relatively resistant one; a few organisms were able to escape the lethal effects of the drug. Whether these persisting gonococci were more resistant than those which succumbed, or were in a resting growth phase or in a situation inaccessible to the drug, is an open question. Thayer, Perry, Magnuson, and Garson (1957) have recently reported that gonococci which had been phagocytosed by Hela cells were protected against the bactericidal action of penicillin for as long as $48 \mathrm{hrs}$.

Sensitivity of Gonococci to Streptomycin.-When it became clear that an appreciable proportion of strains of gonococci were relatively resistant to penicillin, it was thought desirable to determine their sensitivity to streptomycin as the drug of second choice in the treatment of gonorrhoea. The results of tests on strains isolated from 81 patients are given in Table VII, in which the sensitivity of the organism to the two drugs is compared.
No evidence of cross-resistance was found, the strains most resistant to penicillin being sensitive to streptomycin, and the single streptomycin-resistant strain being very sensitive to penicillin. Since this survey was completed two further streptomycinresistant strains have been found, both being resistant to more than $1,000 \mu \mathrm{g} . / \mathrm{ml}$. and one being penicillin-resistant in addition. The three patients concerned all failed to respond to treatment with streptomycin. Cases of streptomycin-resistant gonorrhoea have also been reported by Ryan (1952) and Davey (1957).

Comparison of results with Previously Reported Surveys.-The results obtained in the present investigation are compared with some previous reports by other workers, in Table VIII.

Table VIII shows approximately 15 per cent of the strains of gonococci isolated during the present investigation were more resistant to penicillin than any reported by the previous workers cited. Thayer, Field, Magnuson, and Garson (1957) recently reported that the sensitivities of strains isolated from

TABLE VII

COMPARISON OF SENSITIVITY TO STREPTOMYCIN AND PENICILLIN OF STRAINS OF GONOCOCCI FROM 81 PATIENTS

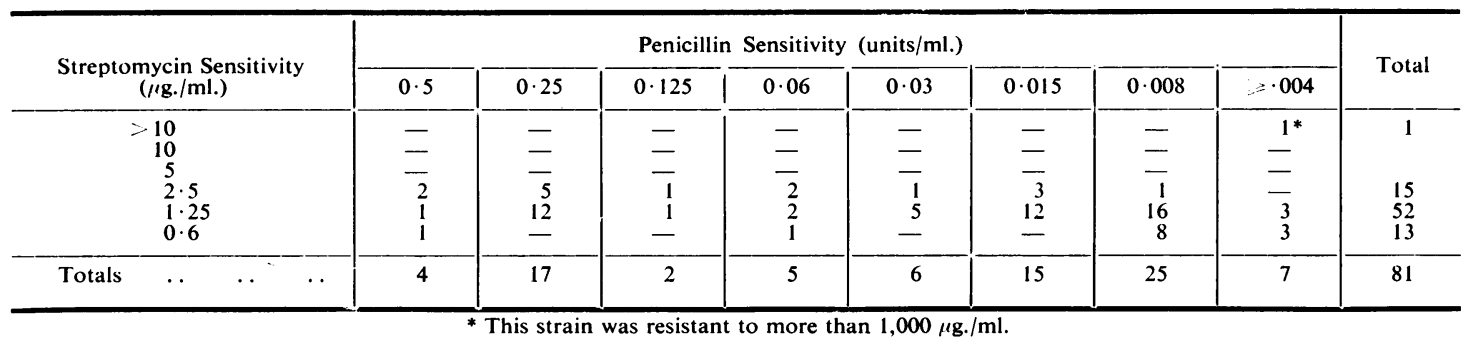

TABLE VIII

COMPARISON OF SOME REPORTED SERIES OF PENICILLIN SENSITIVITIES OF GONOCOCCI*

\begin{tabular}{|c|c|c|c|c|c|c|c|c|c|c|c|}
\hline \multirow{2}{*}{ Author } & & \multirow{2}{*}{ Date of Survey } & \multirow{2}{*}{$\begin{array}{l}\text { No. of } \\
\text { Strains }\end{array}$} & \multicolumn{8}{|c|}{ Percentage of Strains Sensitive (units $/ \mathrm{ml}$.) } \\
\hline & & & & $0 \cdot 5$ & $0 \cdot 25$ & $0 \cdot 125$ & 0.06 & $0 \cdot 03$ & 0.015 & 0.008 & 2.004 \\
\hline Lankford & $\cdots$ & 1945 & 100 & - & - & - & - & 11 & 65 & 24 & - \\
\hline Romansky and Robin & . & 1947 & 53 & - & - & - & $9 \cdot 4$ & $54 \cdot 7$ & $24 \cdot 5$ & $5 \cdot 7$ & $5 \cdot 7$ \\
\hline \multirow{3}{*}{ Del Love and Finland } & \multirow{3}{*}{$\cdots$} & 1947 & 104 & - & - & - & - & 1 & 4 & 79 & 16 \\
\hline & & 1949 & 52 & - & - & 2 & 10 & 37 & 21 & 28 & - \\
\hline & & 1954 (pubd. 1955) & 106 & - & - & - & - & 3 & 11 & 84 & 2 \\
\hline Marcuse and Hussels & $\cdots$ & $1950-52$ (pubd. 1954) & 232 & - & - & 0.4 & $15 \cdot 9$ & $74 \cdot 5$ & $8 \cdot 2$ & 0.9 & - \\
\hline Schümmer and Hubbes & $\cdots$ & 1951 & 100 & - & - & 2 & 5 & 27 & 50 & 14 & 2 \\
\hline Schreus and Schümmer & $\cdots$ & 1951 & 100 & - & - & 1 & 7 & 53 & 35 & 4 & - \\
\hline Present Series.. & $\cdots$ & 1957 & 302 & $1 \cdot 6$ & $12 \cdot 6$ & $5 \cdot 3$ & $5 \cdot 6$ & $6 \cdot 6$ & $24 \cdot 2$ & $31 \cdot 2$ & $12 \cdot 9$ \\
\hline
\end{tabular}

* In compiling this Table, where authors expressed results as the maximum tolerated concentration of penicillin it has been assumed that the next highest concentration was inhibitory. Results expressed in $\mu \mathrm{g}$ or on a different dilution scale have been translated into units on the above dilution scale. 
31 patients fell within the range 0.005 to 0.2 units/ $\mathrm{ml}$. (mean 0.052 units $/ \mathrm{ml}$.). They found no significant differences between the sensitivities of strains isolated from treatment failures and from patients in whom treatment with penicillin had been successful, and they considered that the sensitivity level did not account for the failure of treatment. They noted that their mean level of sensitivity was 1.5 to 10 times the means calculated from the results of Lankford (1945) and Del Love and Finland (1955).

Franks (1946) reported four cases of bacteriologically proved gonorrhoea which were clinically resistant to penicillin and sulphonamides. The gonococci isolated were stated to show no zones of inhibition round cups containing "about 800 units" of penicillin in plate tests of sensitivity. The patients responded satisfactorily to combined sulphonamide - penicillin and/or fever therapy'. Duemling and Horton (1947) reported the results of in vitro tests of sensitivity on gonococci from 24 patients, tests being carried out on ditch plates incorporating known concentrations of penicillin. Eighteen of the strains were not inhibited by 5 units $/ \mathrm{ml}$., and six strains grew on concentrations varying from 20 to 50 units $/ \mathrm{ml}$. Ten of these 24 strains were re-tested after treatment with sulphonamides had failed, and were stated to have become sensitive to penicillin, a finding which has been thought to cast some doubt on the validity of the original observations. Huriez and Desurmont (1947) noted the failure of massive doses of penicillin to cure a minority of patients with gonorrhoea and suggested that penicillin-resistant strains might be emerging, but did not report any bacteriological work in support of this. Other workers e.g. Parkhurst, Harb, and Cannefax (1947), Hughes and Carpenter (1948), and Cohn, Grunstein, Goldberg, and Crane (1949), have investigated cases of allegedly penicillin-resistant gonorrhoea. They concluded that these were due to misdiagnosis of non-gonococcal urethritis as gonorrhoea, through faulty techniques of Gram-staining, or to re-infections, and not to the resistance of gonococci to penicillin.

\section{Part II. Clinical Aspects}

The clinical investigation of the results of treating acute gonococcal urethritis in men with penicillin began about the middle of November, 1956, and was continued to December 31, 1957; the bacteriological work was carried out on about one-quarter of these patients. During this period 1,267 cases of acute gonorrhoea were seen and 132 were found to have gonococci in their urethral discharges at various times after treatment. In 1,116 cases, treatment consisted of an intramuscular injection of 300,000 units of P.A.M. or of an aqueous suspension of procaine penicillin, and 117 of the remaining 151 received an intramuscular injection of $1 \mathrm{~g}$. streptomycin, and the other 34 were given tetracycline or penicillin by mouth or some combination of all these types of treatment. This group of 151 patients supplied eight instances of post-treatment gonorrhoea.

We have therefore a group of 1,116 cases, in 124 of which gonococci were found in urethral discharges after treatment. Sensitivities to penicillin were determined for gonococci isolated from 251 of these patients, of whom 29 showed post-treatment gonorrhoea in the first week (Table IX). It will be noted that the percentages of strains of differing sensitivities to penicillin agree closely with those shown in Table III for the whole group of initial sensitivity determinations. It should be added that only between 50 and 60 per cent. of the patients who produced the strains of gonococci shown at the top of each sensitivity column were observed for one week or more.

The Clinical Picture.-Patients who attended with post-treatment gonorrhoea gave one of the following histories:

(1) The symptoms present at the time of treatment disappeared on either the day of treatment or the day after, and then, after a symptomfree period of 1 or 2 days, the symptoms recurred and persisted.

TABLE IX

POST-TREATMENT GONORRHOEA IN RELATION TO SENSITIVITIES OF GONOCOCCI TO PENICILLIN DETERMINED BEFORE TREATMENT OF THE PATIENTS WITH 300,000 UNITS OF EITHER AQUEOUS PROCAINE PENICILLIN OR P.A.M.

\begin{tabular}{|c|c|c|c|c|c|c|c|c|c|c|c|c|}
\hline \multicolumn{4}{|c|}{ In vitro Sensitivities to Penicillin (units $/ \mathrm{ml}$.) } & $0 \cdot 5$ & $0 \cdot 25$ & $0 \cdot 125$ & 0.06 & $0 \cdot 03$ & 0.015 & $0 \cdot 008$ & $0 \cdot 004$ & Total \\
\hline \multicolumn{2}{|l|}{ No. of Strains } & $\cdots$ & . & 4 & 33 & 13 & 13 & 16 & 48 & 87 & 37 & 251 \\
\hline \multicolumn{2}{|c|}{ Percentage of Total No. } & . & . & $1 \cdot 6$ & $13 \cdot 1$ & $5 \cdot 2$ & $5 \cdot 2$ & $6 \cdot 4$ & $19 \cdot 2$ & $34 \cdot 6$ & $14 \cdot 7$ & 100 \\
\hline \multicolumn{3}{|c|}{ No. of Patients defaulting within $48 \mathrm{hrs}$} & .. & 0 & 7 & 6 & 4 & 4 & 14 & 19 & 7 & \\
\hline \multirow{2}{*}{$\begin{array}{l}\text { No. of Cases show- } \\
\text { ing Post-treatment } \\
\text { Gonorrhoea }\end{array}$} & \multicolumn{3}{|c|}{ (1) With history of re-exposure } & & & & & 1 & & & & 1 \\
\hline & \multicolumn{3}{|c|}{ (2) With no history of re-exposure } & 4 & 17 & 4 & 2 & 1 & & & & 28 \\
\hline
\end{tabular}


(2) The symptoms lessened after treatment but, after a day or two, increased in severity up to the pre-treatment intensity.

(3) The symptoms remained unchanged or even increased after treatment.

Examination of the patients invariably showed a profuse purulent urethral discharge and pyuria. Occasionally, patients with post-treatment gonorrhoea were symptomless, but a purulent urethral discharge with pyuria was found on examination, and the Gram-stained smears of the urethral discharge showed the presence of gonococci. This apparently asymptomatic carrier-state should be borne in mind during the management of gonorrhoea, and all patients should be carefully examined by stripping the urethra and staining the secretion even though most patients may assert that they have recovered. The patient whose eventful history is shown in Table VI (p.73) told one of us (F.R.C.) on October 19 that he had had no discharge and no dysuria since his last injection the previous day but, on examination, he had an obvious urethral discharge and his urine was full of pus.

All except one of the 29 patients denied further risk of infection, but some admitted taking alcohol.

Treatment.-At first, patients were given a second intramuscular injection of 300,000 units of one of the two pencillin preparations mentioned above. Most of them were unimproved and they were then treated with 600,000 units.

Many of these again presented with post-treatment gonorrhoea and were finally cured by a single intramuscular injection of 1 or $2 \mathrm{~g}$. streptomycin. Fortunately it has so far been rare to find an organism insensitive to both penicillin and streptomycin.

\section{Discussion}

Cohn and Seijo (1944), examining strains of gonococci, some of which were resistant, some sensitive to sulphonamides, found that all strains were killed by $0 \cdot 176$ units penicillin per ml. and only three survived exposure to 0.0176 units $/ \mathrm{ml}$. Romansky and Robin (1947), extending and confirming these findings and those of Romansky (1946), found that 79.2 per cent. of strains of gonococci tested were sensitive in vitro to between 0.0156 and 0.0313 units penicillin per ml. Romansky (1946) noted that one strain of gonococci required $\mathbf{0 . 3}$ units $/ \mathrm{ml}$. for in vitro death, but stated that the patient responded to a single injection of 300,000 units of penicillin in oil and beeswax. This work appeared to show that the level of penicillin in blood and tissues required to inhibit or kill gonococci was 0.03 to 0.06 units per ml. and this became the standard to which new preparations of penicillin were designed to conform.

Table X gives a selection of serum penicillin levels after the intramuscular injection of 300,000 units aqueous procaine penicillin and procaine penicillin in oil with 2 per cent. aluminium monostearate (P.A.M.). It will be seen that blood levels adequate to kill gonococci whose resistance to penicillin in vitro extends to 0.5 units $/ \mathrm{ml}$. are seldom reached for long enough to ensure a good therapeutic result. Hence the number of cases of post-treatment gonorrhoea recorded in Table IX. Fairbrother and Daber (1950) found that, 24 hours after the intramuscular injection of 300,000 units aqueous procaine penicillin seven out of 49 patients had no assayable level of penicillin in the serum.

The remaining 24-hr assays showed an average of 0.13 units $/ \mathrm{ml}$. penicillin with a range of 0.03 to 0.5 units $/ \mathrm{ml}$. The wide range of values for serum penicillin after intramuscular injection of different preparations of P.A.M. is shown in several graphs (W.H.O., 1953) in which, eighteen of eighty patients had no assayable penicillin at 24-hrs. while the averages for eight groups of ten treated with a different preparation of P.A.M. ranged from 0.02 to 0.22 units/ml. at 24-hrs.

TABLE $X$

SERUM PENICILLIN LEVELS AFTER INTRAMUSCULAR INJECTION OF 300,000 UNITS OF PREPARATION INDICATED

\begin{tabular}{|c|c|c|c|c|c|c|c|c|c|c|c|c|c|c|c|c|}
\hline \multirow{2}{*}{$\begin{array}{l}\text { Author and } \\
\text { and Date }\end{array}$} & \multirow{2}{*}{$\begin{array}{l}\text { No. of } \\
\text { Patients }\end{array}$} & \multirow{2}{*}{ Preparation } & \multicolumn{14}{|c|}{ Serum Penicillin (units/ml.) after so many Hours } \\
\hline & & & \multicolumn{2}{|c|}{$1 \mathrm{hr}$} & \multicolumn{2}{|c|}{$2 \mathrm{hrs}$} & \multicolumn{2}{|c|}{$4 \mathrm{hrs}$} & \multicolumn{2}{|c|}{$8 \mathrm{hrs}$} & \multicolumn{2}{|c|}{$12 \mathrm{hrs}$} & \multicolumn{2}{|c|}{$18 \mathrm{hrs}$} & \multicolumn{2}{|c|}{$24 \mathrm{hrs}$} \\
\hline & & & Av. & Range & Av. & Range & Av. & Range & Av. & Range & Av. & Range & Av. & Range & Av. & Range \\
\hline Cohen (1950) & 12 & $\begin{array}{l}\text { Aqueous } \\
\text { Procaine } \\
\text { Penicillin }\end{array}$ & $0 \cdot 77$ & $\begin{array}{l}0 \cdot 25 \\
\text { to } \\
1 \cdot 0\end{array}$ & $1 \cdot 09$ & $\begin{array}{c}0 \cdot 5 \\
\text { to } \\
2 \cdot 0\end{array}$ & 0.96 & $\begin{array}{c}0.5 \\
\text { to } \\
2 \cdot 0\end{array}$ & 0.65 & $\begin{array}{l}0 \cdot 25 \\
\text { to } \\
1 \cdot 0\end{array}$ & $0 \cdot 25$ & $\begin{array}{c}0.125 \\
\text { to } \\
0.5\end{array}$ & $0 \cdot 163 \mid$ & $\begin{array}{c}0.06 \\
\text { to } \\
0 \cdot 25\end{array}$ & 0.08 & $\begin{array}{l}0.06 \\
\text { to } \\
0 \cdot 125\end{array}$ \\
\hline \multirow[t]{2}{*}{ Guthe (1957)* } & & $\begin{array}{l}\text { Aqueous } \\
\text { Procaine } \\
\text { Penicillin }\end{array}$ & $0 \cdot 6$ & & - & & - & & - & & $0 \cdot 25$ & & $0 \cdot 15$ & & 0.06 & \\
\hline & & P.A.M. & $0 \cdot 25$ & & - & & - & & - & & $0 \cdot 2$ & & $0 \cdot 15$ & & $0 \cdot 125$ & \\
\hline
\end{tabular}

* Figures shown were read from graphs which show average levels for an unstated number of patients. 
Examination of blood levels of penicillin obtained with greater dosage of the same preparations and also with other preparations of penicillin (Table XI, overleaf) shows that 600,000 units of an aqueous suspension of procaine penicillin or $1,200,000$ units of Penidural A.P.* are likely to produce the best results in infections with the more resistant strains of gonococci. Tommila and Savolainen (1955) compared the results of injecting intramuscularly 600,000 units aqueous procaine penicillin preparations from different sources, and Table XI shows the wide range of values they obtained. Rein, Buckwalter, Mann, Landy, and Flax (1953) showed similar variations in patients injected intramuscularly with $1,200,000$ units of Penidural A.P. (Table $\mathrm{XI})$.

In 1955-6, 923 male patients attending the Whitechapel Clinic with acute gonorrhoea were treated with $1,200,000$ units Penidural A.P. or 300,000 units procaine penicillin suspended in water. In the first week, three cases of post-treatment gonorrhoea occurred out of 445 patients treated with Penidural, and seventeen out of 478 patients treated with aqueous procaine penicillin. This favourable effect of Penidural is in nu way due to the benzathine penicillin contained in the preparation. In fact, one of these three cases was found to have gonorrhoea on the sixth day after treatment and also had 0.03 units $/ \mathrm{ml}$. penicillin in blood taken the same day. A current trial in the Whitechapel Clinic of treatment of male gonorrhoea with four different preparations of penicillin shows, in a preliminary analysis, that Penidural A.P. is effective, while 600,000 units benzathine penicillin alone gives worse results than 600,000 units of either P.A.M. or aqueous procaine penicillin. Moreover, there may be a real danger that, in using benzathine penicillin with its prolonged duration of 0.03 to 0.06 units per $\mathrm{ml}$. in the bloodstream and tissues, some patients with gonorrhoea may be converted into living test tubes for producing resistant strains of gonococci either from the infecttion for which they were originally treated or from infections obtained by subsequent exposures during the 2 to 3 weeks duration of these low penicillin levels. There may also be a risk of patients becoming asymptomatic carriers, as mentioned above.

In view of the occurrence of about 20 per cent. of strains of gonococci with sensitivities above 0.06 units $/ \mathrm{ml}$. it is no longer valid to regard 0.03 to 0.06 units $/ \mathrm{ml}$. as the therapeutic blood level for gonococcal infections, and it therefore seems that there is

\footnotetext{
* Penidural A.P. consists of 300,000 units crystalline penicillin G., 300,000 units procaine penicillin, and 600,000 units benzathine penicillin contained in a single dose of $2 \mathrm{ml}$.

Penidural L.A. consists of 600,000 units benzathine penicillin in a volume of $2 \mathrm{ml}$.
}

need for a new preparation of penicillin which will reach a level in the tissues of $1 \mathrm{unit} / \mathrm{ml}$. penicillin, maintain this level for 18 to $24 \mathrm{hrs}$, and then rapidily fall to zero. At the present time it seems that the intramuscular injection of 600,000 to $1,200,000$ units aqueous procaine penicillin with or without a "booster" dose of crystalline penicillin G is likely to give the best results without undue prolongation of useless and perhaps dangerous levels of penicillin in blood and tissues.

Microscopic examination of urethral Gramstained smears may show the presence of larger forms of gonococci. If present, they are usually extracellular; they can be seen to be obviously larger than the intracellular organisms and are often more deeply stained. The larger forms are found only in those cases in which, at the time of taking the specimens of urethral discharge, penicillin is still probably present in the tissues. Hence they are found more frequently in post-treatment urethral discharges after the administration of benzathine penicillin, though they may occasionally be seen, after P.A.M.

The presence of larger forms of gonococci in secretions of patients treated with penicillin has been recognized from the early days and was described by Miller, Scott, and Moeller (1944), who thought they represented degenerating forms of gonococci. This must now be regarded as doubtful, as it is perhaps more likely that the increased size may, at any rate in the early stages, be part of an attempted adaptive reaction against lethal or sublethal concentrations of penicillin - the race, in fact, between adaptation and death. It is noteworthy that gonococci subcultured repeatedly on to media containing increasing concentrations of penicillin, manifest similar changes, i.e. they become larger and more deeply staining than other cocci of the same strain, age, and number of subcultures.

Though we are aware that other workers are investigating the problem of varying gonococcal sensitivity to penicillin in relation to post-treatment gonorrhoea, we do not know whether their results in any way resemble ours, or whether our results are due to purely local causes; still less do we know whether increased resistance to penicillin is likely to be encountered in strains of gonococci found in other parts of the United Kingdom. It is to be hoped that these problems will be investigated.

\section{SUMMARY}

(1) Estimations of the sensitivity to penicillin of 302 strains of gonococci obtained before treatment are reported. 
SERUM PENICILLIN LEVELS AFTER INTRAMUSCURAR

\begin{tabular}{|c|c|c|c|c|c|c|c|c|c|c|c|c|}
\hline Author and Date & $\begin{array}{l}\text { Preparation } \\
\text { Dose }\end{array}$ & $\begin{array}{l}\text { No. of } \\
\text { Patients }\end{array}$ & Average & Range & $\begin{array}{l}\text { No. of } \\
\text { Patients }\end{array}$ & Average & Range & $\begin{array}{l}\text { No. of } \\
\text { Patients }\end{array}$ & Average & Range & $\begin{array}{l}\text { No. of } \\
\text { Patients }\end{array}$ & Average \\
\hline $\begin{array}{l}\text { Tommila and } \\
\text { Savolainen } \\
\text { (1955) }\end{array}$ & $\begin{array}{l}\text { Aqueous Procaine } \\
\text { Penicillin } \\
\text { (600,000 units) }\end{array}$ & - & - & - & 47 & 0.56 & $\begin{array}{c}0 \cdot 14 \\
\text { to } \\
1 \cdot 64\end{array}$ & - & - & - & - & - \\
\hline \multirow{2}{*}{$\begin{array}{l}\text { Rein, Buckwalter, } \\
\text { Mann, Landy, } \\
\text { and Flax (1953) }\end{array}$} & $\begin{array}{l}\text { P.A.M.* } \\
(1,200,000 \text { units })\end{array}$ & - & 0.46 & - & - & - & - & - & - & - & - & - \\
\hline & $\begin{array}{l}\text { "Panbiotic"* } f \\
(1,200,000 \text { units })\end{array}$ & - & $3 \cdot 18$ & - & - & - & - & - & - & - & - & - \\
\hline & $\begin{array}{l}\text { Benzathine } \\
\text { Penicillin* } \\
(600,000 \text { units) }\end{array}$ & - & $0 \cdot 17$ & - & - & - & - & - & - & - & - & - \\
\hline
\end{tabular}

* Figures shown were read from graph.

(2) These strains show $19 \cdot 5$ per cent. of gonococci with sensitivities between 0.125 and 0.5 units of penicillin per $\mathrm{ml}$.

(3) Post-treatment gonorrhoea in the first week after 300,000 units of aqueous procaine penicillin or P.A.M. had been given occurred mainly at these sensitivity levels and in no proven case below 0.03 units $/ \mathrm{ml}$.

(4) It is suggested that 600,000 to $1,200,000$ units aqueous procaine penicillin injected intramuscularly should be the routine dose for acute gonorrhoea, but that efforts should be made to devise a preparation of penicillin which would give a blood level of not less than $1 \mathrm{unit} / \mathrm{ml}$. for not less than $24 \mathrm{hrs}$, and, preferably, for not much longer, owing to the risk that long-lasting low levels of penicillin may produce more resistant strains of gonococci or asymptomatic carriers.

Penidural A.P. and L.A. are names used by John Wyeth and Brother, Ltd., to whom one of us (F.R.C.) is greatly indebted for supplies of both preparations. Our thanks are due also to Dr. G. R. Fryers, Medical Adviser to that Company.

\section{REFERENCES}

Chief Medical Officer, Annual Report (1957). Brit. J. vener. Dis., $33,54$.

Cohen, R. I. (1950). Lancet, 1, 622.

Cohn, A., Grunstein, I., Goldberg, R., and Crage, J. (1949). Amer. J. Syph., 33, 86.

and Seijo, I. H. (1944). J. Amer. med. Ass., 124, 1125.

Davey, A. C. C. (1957). Brit. J. vener. Dis., 33, 179

Del Love, B., and Finland, M. (1955). Arch. Intern. Med., 95, 66.

Duemling, W. W., and Horton, S. H. (1947). U.S. Naval med. Bull. (Wash.), 47, 605.

Fairbrother, R. W., and Daber, K. S. (1950). Brit. med. J., 1, 1098.
Franks, A. G. (1946). Amer. J. med. Sci., 211, 553.

Guthe, T. (1957). W.H.O./V.D.T./238.

Hughes, R. P., and Carpenter, C. M. (1948). Amer. J. Syph., 32, 265

Huriez, C., and Desurmont, M. (1947). Presse méd., 55, 13.

King, A. (1958). Lancet, 1, 651.

Lankford, C. E. (1945). Amer. J. Syph., 29, 56.

Marcuse, K., and Hussels, H. (1954). Derm. Wschr., 130, 1031.

Miller, C. P., Scott, W. W., and Moeller, V. (1944). J. Amer. med. Ass., $125,607$.

Moffatt, M., Young, J. L., and Stuart, R. D. (1948). Brit. med. J., $2,42 i$.

Parkhurst, G. E., Harb, F. W., and Cannefax, G. R. (1947). J. vener. Dis. Inform., 28, 211

Rein, C. R., Buckwalter, F. H., Mann, C. H., Landy, S. E., and Flax, S. (1953). J. invest. Derm., 21, 435.

Romansky, M. J. (1946). Amer. J. Med., 1, 395.

-, and Robin, E. V. D. (1947). Amer. J. Syph., 31, 271.

Ryan, W. J. (1952). Brit. J. vener. Dis., $28,209$.

Schreus, H. T., and Schümmer, H. (1951). Zeit. Haut-und Geschl. Krankheit., 11, 229.

Schümmer, H., and Hubbes, A. (1951). Hautarzt, 2, 500.

Stokes, E. J. (1955). "Clinical Bacteriology". Arnold, London.

Thayer, J. D., Field, F. W., Magnuson, H. J., and Garson, W. (1957). Antibiot. and Chemother., 7, 306.

Perry, M. I., Magnuson, H. J., and Garson W. (1957). Ibid., 7, 311 .

Tommila, $\mathrm{V}_{\text {., }}$ and Savolainen, T. (1955). Ann. Med. exp. Fenn.,

W.H.O. (1953). Tech. Rep. Ser., No. 63, p. 24.

\section{DISCUSSION}

The President, Dr. S. M. LaIRD (Manchester), congratulated both openers on their papers and said that, from the point of view of epidemiology and treatment policy, these two papers were perhaps the most important that the Society had listened to for some considerable time. It was often difficult to decide whether the persistence of urethritis and gonococci represented treatment failure or re-infection, and the position with regard to gonorrhoea was becoming reminiscent of the early days of the penicillin treatment of early syphilis when relapse versus re-infection was hotly debated. It was clear that quantitative sensitivity tests as developed and described by Dr. Wilkinson were essential in these cases in the same way as quantitative serological tests were important in the management of early syphilis. Dr. Curtis was most 